\title{
TRANSFER PRICING IN A FUNCTION OF ABUSING TAX COMPETITION INSTRUMENTS
}

\author{
Ljiljana Tanasić* \\ Faculty of Economics Brčko, University of East Sarajevo, \\ Bosnia and Herzegovina \\ Teodor Petrović \\ Faculty of Economics Brčko, University of East Sarajevo, \\ Bosnia and Herzegovina
}

\begin{abstract}
The paper focuses on elucidating transfer pricing as a means of tax competition instruments misuse. Tax competition instruments have a key role in creating national tax attractiveness for foreign direct investment. However, in order to protect the local tax base on the basis of abuse of tax competition instruments, a large number of countries apply the principle of sources of income, i.e. taxation of business profits made by a non-resident legal entity exclusively in the country where the business was conducted and revenue generated. But with the process of globalization and the expansion of multinational companies, i.e. related legal entities, the instruments of tax competition have remained a suitable area of legally permitted transfer of profits through the application of transfer pricing. The data presented in the paper indicate that, although the trend of global corporate tax rate (as the dominant instrument of tax competition) has a downward trajectory, there are still fluctuations in rates between countries around the world, including the existing inconsistencies and ambiguities of national tax regulations. Taking this into account, the aim of the paper was to emphasize that transfer prices, through the instruments of tax competition, have threatened the economic, social, and tax stability of individual countries for more than two decades. The paper shows that developed countries have managed, to a certain extent, to gain control over their application by introducing more aggressive tax audits of transfer pricing. However, special attention is paid to developing countries which remain an active source of tax competition instruments abuse through the inadequate application of transfer pricing, due to the lack of adequate regulatory and control mechanisms, financial and human resources, and efforts to attract foreign investment through various instruments of tax competition.
\end{abstract}

\footnotetext{
*ljiljana.tanasic.efb@gmail.com.
} 
Key words: transfer pricing, tax competition instruments, profit tax rate, tax incentives, tax havens

JEL classification: $M 41, H 26, F 23$

\section{TRANSFERNE CENE U FUNKCIJI ZLOUPOTREBE INSTRUMENATA PORESKE KONKURENCIJE}

Sažetak: U radu je pažnja usmerena na rasvetljavanje transfernih cena kao sredstva zloupotrebe instrumenata poreske konkurencije. Instrumenti poreske konkurencije imaju primarnu ulogu pri kreiranju nacionalne poreske privlačnosti za direktne strane investicije. Međutim, u cilju zaštite lokalne oporezive osnovice po osnovu zloupotrebe instrumenata poreske konkurencije, veliki broj zemalja primenjuje princip izvora prihoda, odnosno oporezivanje dobiti od poslovanja koje ostvari nerezidentno pravno lice isključivo u zemlji u kojoj je poslovanje obavljeno, tj. prihod kreiran. Ali sa procesom globalizacije $i$ širenjem poslovanja multinacionalnih kompanija, odnosno povezanih pravnih lica, instrumenti poreske konkurencije ostali su pogodno područje zakonski dozvoljenog iznošenja dobiti putem primene transfernih cena. Podaci prikazani u radu ukazuju da, iako trend kretanja globalne stope poreza na dobit (kao dominantnog instrumenta poreske konkurencije) ima silaznu putanju, još uvek su izražene oscilacije u stopama između zemalja širom sveta, uključujući $i$ postojeće nepodudarnosti i nedorečenosti nacionalnih poreskih propisa. Uzimajući to u obzir, cilj rada je bio da se naglasi da transferne cene, preko instrumenata poreske konkurencije, već više od dve decenije ugrožavaju ekonomsku, socijalnu i poresku stabilnost pojedinih zemalja. U radu je prikazano da su razvijene zemlje uvođenjem agresivnijih poreskih revizija transfernih cena uspele, u određenoj mjeri, da ostvare kontrolu nad njihovom primenom. Međutim, posebna pažnja je skrenuta na zemlje u razvoju koje zbog, sa jedne strane, odsustva adekvatnih regulatornih $i$ kontrolnih mehanizama, finansijskih $i$ kadrovskih resursa, a sa druge strane, nastojanja da putem različitih instrumenata poreske konkurencije privuku strane investicije, $i$ dalje predstavljaju aktivno žarište zloupotrebe instrumenata poreske konkurencije putem neadekvatne primene transfernih cena.

Ključne reči: transferne cene, instrumenti poreske konkurencije, stopa poreza na dobit, poreski podsticaji, poreska utočišta

\section{INTRODUCTION}

Globalization, as an inevitable phenomenon from the end of the 20th century, is a process with a pronounced tendency to develop free trade, including the flow of people, goods, and capital. Reducing legal barriers for the movement of 
capital and goods has contributed to the intensification of trade between countries, and encouraged investments in other countries in the form of foreign direct investments.

At the same time, one of the main carriers of the concept of globalization in the context of increasing international trade are multinational companies (MNCs), i.e. multinational business entities, which have become significant when it comes to indirectly increasing the participation of developing countries in international trade through foreign direct investments. For this reason, countries that want to increase foreign direct investments, emphasize the concept of appropriate instruments of tax competition in the field of direct taxes (primarily corporate income tax) when formulating their tax policy, in a way that should attract foreign investors. They introduce income tax rates that are lower than in other countries, allow different types of tax incentives and exemptions, while some completely waive income based on taxation of realized profits (Elkins, 2016, p. 912). Such countries receive the status of "tax havens" because they represent countries with a more favorable tax climate, low (or zero) corporate tax rates, and a high degree of banking and business secrecy (Davies, Martin, Parenti \& Toubal, 2018, p. 127). As a rule, they have moderate or simple financial regulation, a relatively large number of financial institutions primarily dealing with non-residents, which emphasize banking secrecy and anonymity, where the legislation of these countries allows the establishment of companies of unknown origin within their borders, protecting the owner's identity through the guarantee of absolute secrecy (e.g. there is no obligation to enter the name of the owner or director in the court register, etc.). In other words, these are jurisdictions or territories that have deliberately adopted a fiscal and legal framework that allows non-residents to minimize the amount of taxes they pay when undertaking significant economic activity (Berkhout, 2016, p. 11). However, given that a significant number of countries has introduced the obligation to pay income tax in the source country, as a protective mechanism against the export of profits from the country and in order to protect the local budget, transfer pricing came to the fore as a means of transferring profits to appropriate tax havens. Transfer pricing is on the very border between legal and illegal tax evasion or reduction, because it enables the exploitation of prices of products and services in relation with related parties. Specifically, lowering sales prices to related parties operating in an area with a low or zero tax burden, while at the same time unjustifiably increasing the cost of procurement from them, leads to a reported transfer of profits and "legal" abuse of tax regulations in different countries with the aim of creating low or even zero tax liabilities. 
In the next part of the paper, the basic instruments of tax competition in the segment of taxation of realized profit are listed and explained, as well as how the application of transfer pricing, in accordance with certain interests, can lead to their abuse. For that purpose, appropriate scientific methods were used, such as: the method of description, comparative method, method of analysis and synthesis, method of content analysis, method of generalization, etc.

In this way, the intention was to point out that tax evasion has become a reality and a growing phenomenon in most tax systems due to the application of transfer pricing in the misuse of tax instruments of different countries.

\section{BASIC INSTRUMENTS OF TAX COMPETITION IN THE DOMAIN OF PROFIT TAXATION}

Some authors (domestic and foreign), such as Mikerević (2011), Paić (2012), Pezerović (2012, 2013), Jakšić, Andrić and Mijić (2014), but also Adams and Drtina (2010), Rectenwald 2012), Pak (2012), point out in their works that an important component for survival, growth, and development within the business environment is precisely the tax environment, and in terms of considering the effects of transfer pricing by related legal entities (multinational corporations or domestic economic groups) the emphasis is placed primarily on tax implications. These authors emphasize that the existing discrepancy between global capital mobility and national tax jurisdictions puts national tax authorities in a disturbing position when it comes to trying to identify and separate the global profits of legal entities and obtain tax relief in the local area. In other words, one must not forget that transfer pricing is not only an accounting technique, but also a way of allocating funds and tax avoidance that affects the distribution of income, wealth, as well as the quality of life itself (Sikka \& Willmott, 2010, p. 352). For this reason, in recent years, there has been a growing awareness of developing countries about the negative challenges of transfer pricing as a dominant means of conducting business transactions between related legal entities and the need to introduce transfer pricing regulations (Lohse, Riedel \& Spengel, 2014).

However, the emergence of tax policy instruments materialized in the tax system has created completely new opportunities for, on one hand, legal entities in terms of minimizing and avoiding tax liabilities and, on the other hand, individual countries to develop tax systems that would primarily aim to attract foreign investors. Greater investment needs, which is the case with developing countries and countries in transition, lead to the emergence and strengthening of the intensity of tax competition. The most successful countries in transition are precisely those countries that have managed to achieve a significant inflow of 
foreign capital by providing preferential tax treatment to foreign investors through various reliefs in the income tax system, but also through other necessary general economic and social conditions. Increased inflow of foreign capital entails numerous benefits such as: easier transfer of knowledge and new technologies, GDP growth, employment rates and living standards, easier access to developed markets and increased exports, more efficient budget filling, etc.

However, tax competition also brings about a negative effect that is expressed through the creation of significant distortions in international trade and investment flows, which represents the so-called harmful tax competition. Harmful tax competition results in the attraction of foreign economic entities, but only for tax reasons. This type of competitive pressure imposes the need to modify national tax systems in order to avoid or reduce the respective "spillover effect", which increases opportunities and expands the space on the international business scene for finding different legal ways to reduce tax liability based on profits.

The basic instruments that participate in creating the tax competitiveness of a country in the field of corporate taxation are:

- nominal (legally prescribed) tax rate,

- tax treatment of accrued revenues and expenses,

- tax incentives and tax exemptions.

In terms of nominal tax rates, as a means of tax competition, the low nominal income tax rate is treated positively by investors, and the tax system characterized by a low tax rate has fewer exemptions as a rule, and is considered relatively neutral, that is, simple and transparent. It is evident that the differences between nominal income tax rates have an impact on the level of foreign direct investments.

From the aspect of the tax treatment of accrued revenues and expenses, a tax system that, on the one hand, has several exemptions from accrued income taxes, and on the other hand, allows or recognizes more accrued expenses for tax purposes (certainly their amount is also important, not just the number) is considered a more competitive tax system.

Tax incentives and exemptions cause great confusion and discussions regarding the need for their (non) existence, due to possible negative consequences for the market and the fiscal system itself. The basic issues that must be taken into account when granting tax relief are:

- what are the possible side effects of tax relief, primarily the extent to which they can cause tax evasion,

- the extent to which market neutrality is undermined, 
- whether the incentive measures in the corporate income tax system are synchronized in such a way that they are not mutually annulled and

- whether the tax administration of a certain tax system is able to respond to the requirements of the control of that tax system.

Tax incentives and tax exemptions are a reflection of active tax policy, with the aim to stimulate the desired behavior of economic entities, i.e. taxpayers. However, the practice has shown that the positive effects of tax incentives can be disrupted and ruined by their abuse. Tax incentives are a stimulus and a legally provided space to favor short-term and even speculative investments, in terms of a conscious invasion of income through high costs through related legal entities from jurisdictions with high effective income tax rates to jurisdictions with low or zero effective rates. It is estimated that developing countries lose over $\$ 100$ billion annually due to the misuse of tax reliefs (Berkhout, 2016, p. 3; Jansky \& Prats, 2015, p. 275).

A large number of tax reliefs, incentives, exemptions on several different bases, increases the complexity and endangers the transparency of the tax system, thus raising the question of the ability of the tax administration to conduct appropriate tax control within such a tax system. For this reason, the decision of the taxing authorities when creating certain tax incentives must be based on an appropriate "cost-benefit" analysis in order to preserve a certain, necessary minimum income and preserve the basic purpose of their introduction.

The pronounced intensity of the application of various tax competition instruments in order to attract foreign direct investment has reduced the distortion between the prescribed nominal tax rates, and only a small number of countries still have extremely high corporate tax rates (Figure 1).

According to the data used, the Figure 1 shows that in 2019, 79 out of 218 countries (which participated in the data processing), had a profit tax rate of up to $20 \%, 111$ countries $20-30 \%, 26$ countries $30-40 \%$, and only 2 countries in the world had a profit tax rate of over $40 \%$. 


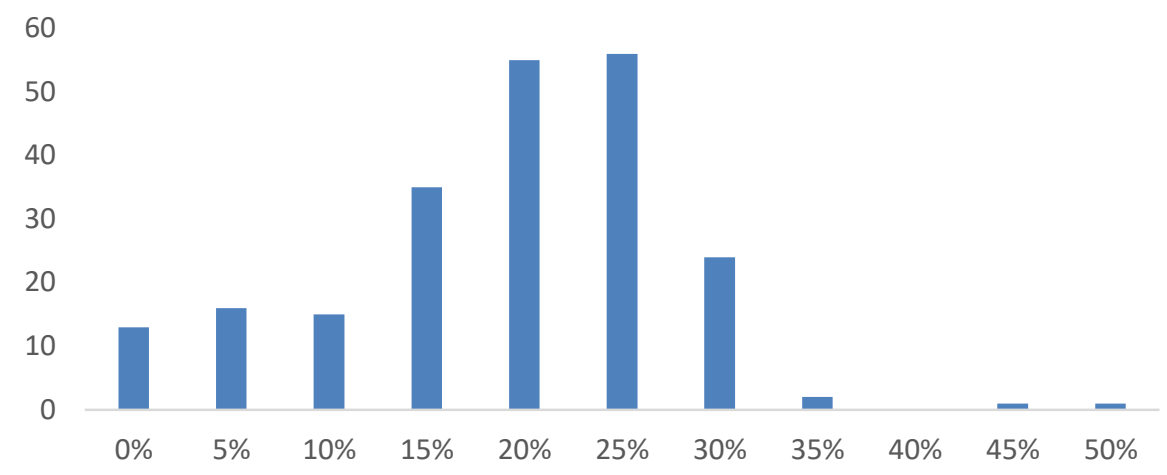

Figure 1. Distribution of the corporate income tax rate in the world in 2019

Note. Retrieved from Tax Foundation (2019). Corporate Income Tax Rate around the World. Retrieved from: https://taxfoundation.org/publications/corporate-tax-ratesaround-the-world

In the period 2003-2019, there was a trend of average corporate tax rate decrease in all regions of the world (but not their equalization). The largest absolute decline in the average corporate tax rate, as shown in Figure 2, was recorded in Asia where there was about 9 percent decline (from 30.19\% to $21.18 \%$ ), while the smallest absolute decline was recorded in Oceania, 1.7 percent (from $30.20 \%$ to $28.43 \%$ ).

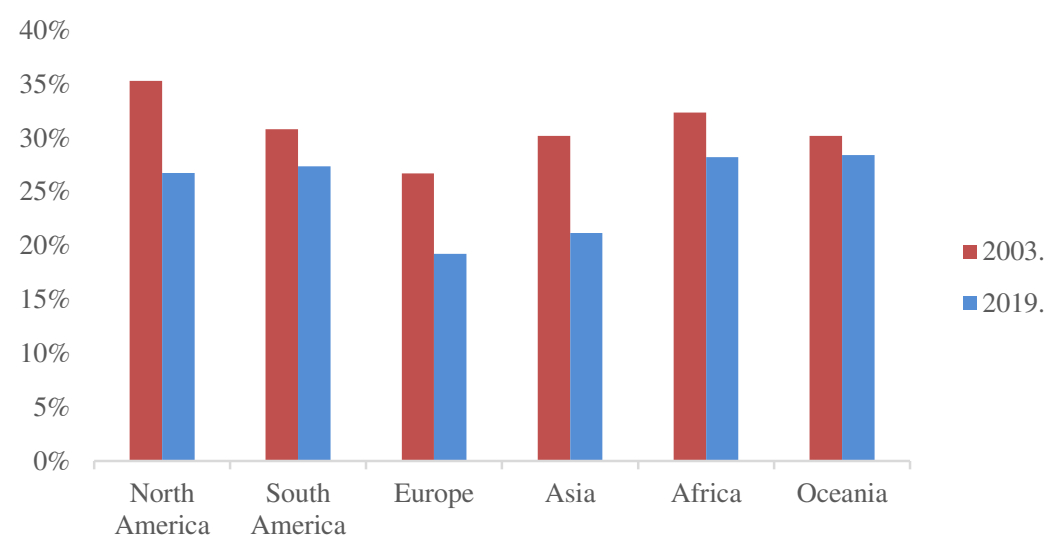

Figure 2. Decrease in the average corporate tax rates by regions in 2003/2019

Note. Prepared by authors based on data retrieved from KPMG, Corporate tax rates table. Retrieved from: https://home.kpmg.com/xx/en/home/services/tax/tax-tools-andresources/tax-rates-online/corporate-tax-rates-table.html 
The decrease in average corporate tax rates in countries around the world consequently led to a reduction in the world average tax rate (Figure 3). In 2003, the world average was around $30 \%$ and by 2019 it fell by slightly more than 6 percent to $23.81 \%$.

The income tax rate is one of the key characteristics of a country's tax attractiveness as an investment economy. Although the data presented in the charts show a general decline in corporate income tax rates in the world, the differences by regions indicate that the corporate tax rate remains a significant instrument of tax competition. Also, within the regions themselves, there are significant oscillations when it comes to corporate tax rates in developing countries and developed countries. For this reason, in an effort to emphasize the existing diversity in terms of prescribed corporate income tax rates within a region, the following table provides an overview of corporate income tax rates in 2019 in individual European countries, emphasizing the comparison of former Yugoslavian countries and some developed European countries in the region, members of the European Union (EU).

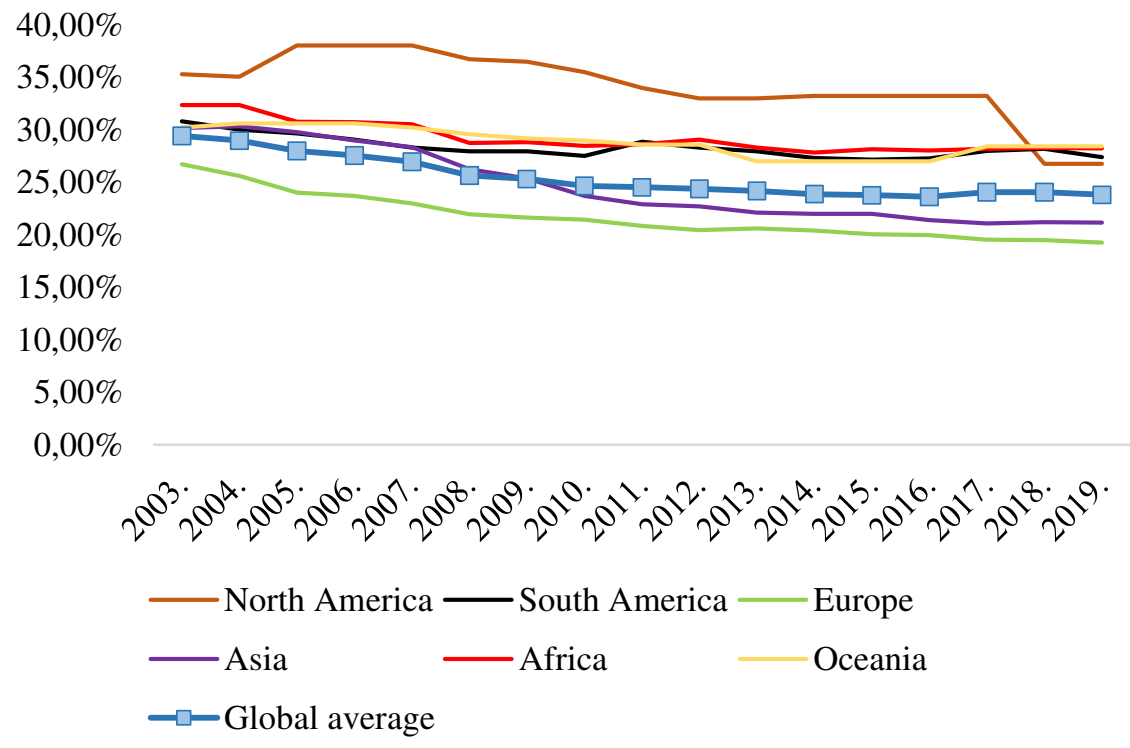

Figure 3. Global corporate tax rate trend for the period 2003-2019

Note. Prepared by authors based on data retrieved from KPMG, Corporate tax rates table. Retrieved from: https://home.kpmg.com/xx/en/home/services/tax/tax-tools-andresources/tax-rates-online/corporate-tax-rates-table.html 


\section{Table 1}

Variety of corporate tax rates in some European countries

\begin{tabular}{|l|c|c|c|c|c|c|}
\hline $\begin{array}{l}\text { Former } \\
\text { Yugoslavian } \\
\text { countries }\end{array}$ & Serbia & Slovenia & Croatia & $\begin{array}{c}\text { Bosnia and } \\
\text { Herzegovina }\end{array}$ & Montenegro & Macedonia \\
\hline $\begin{array}{l}\text { Prescribed } \\
\text { income tax } \\
\text { rates }\end{array}$ & 15 & 19 & 18 & 10 & 9 & 10 \\
\hline $\begin{array}{l}\text { European } \\
\text { countries }\end{array}$ & Germany & Italy & Austria & France & Netherlands & Belgium \\
\hline $\begin{array}{l}\text { Prescribed } \\
\text { income tax } \\
\text { rates }\end{array}$ & 30 & 24 & 25 & 31 & 25 & 29 \\
\hline
\end{tabular}

Note. Prepared by authors according to data retreived from Deloitte. Deloitte International Tax Guide. Retrieved from https://dits.deloitte.com/\#TaxGuides

The data show significant ranges in terms of existing corporate tax rates. It is evident that former Yugoslavian countries have significantly lower rates compared to developed European countries. Also, by comparing only former Yugoslavian countries, it can be seen that EU member countries have higher corporate tax rates compared to candidate and potential candidate countries. On the other hand, there are certain variations among the developed EU member states in terms of nominal corporate tax rates, while in the entire territory of the EU this disparity is very pronounced. According to the Deloitte International Tax Guide (https://dits.deloitte.com/\#TaxGuides), the maximum income tax rate in 2019 in the EU was 35\% (Malta), and the minimum was 9\% (Hungary). In her 2012 work, that is based on the appropriate results of research on the situation in EU member states, Paić points out that despite the pronounced public tendency to harmonize direct taxes (primarily corporate income tax), corporate tax rates as well as rules and regulations on determining the tax base are not harmonized. The fact that this practice has continued was confirmed by Chirculescu in his 2018 paper, which indicated that EU member states continued to retain their sovereignty in the field of direct taxation (even when it comes to income taxation, with appropriate harmonization of regulations to avoid double international taxation), and that they practice bidding to attract jobs and companies in a country through tax reliefs.

In an effort to protect the local budget against the transfer of taxable profit to other more attractive tax jurisdictions, a significant number of countries have opted for the introduction of a legal obligation to pay income tax in the source country, i.e. in the country of realization (acquisition) of that profit. However, with the process of globalization and the spread of the concept of different 
business combinations, i.e. with the emergence of related legal entities and, on that basis, more intensive application of transfer pricing, tax competition instruments have remained a suitable area of abuse, in line with the need to transfer profits in order to reduce the tax liability.

\section{THE ABUSE OF TAX COMPETITION INSTRUMENTS THROUGH TRANSFER PRICING}

In a business economy, transfer pricing is the amount that a related legal entity charges to another related legal entity for a delivered product/service or property, within the same economic entity. In this way, through transfer pricing, financial resources are allocated in a reasonable way to different members of that economic unit, i.e. group (Cottani, 2018). Although, at first glance, the relevant definition does not indicate the possibility of abuse, detailed analysis shows a deep involvement of transfer pricing in increasing the wealth of the group itself, by creating an adequate cost and revenue structure in accordance with the interests of the group and its participants, which creates a possibility for "justified" exploitation of existing tax competition instruments in different tax jurisdictions (Figure 4). Such behavior falls under aggressive tax planning, because it leads to a reduction of the tax liability by legal acts that are legal, but the intention of the taxpayer is contrary to the goal of the legislator.

In this light, multinational business entities, i.e. multinational companies (MNCs) have a wide range of opportunities for tax planning, i.e. have the freedom of legally allowed choice in terms of several factors:

- locations of the company's main headquarters, as well as branches and affiliates,

- conducting sales,

- calculation of business expenses,

- employment of workers,

- borrowing money,

- registration of intellectual property rights,

- claims for tax benefits, etc. 


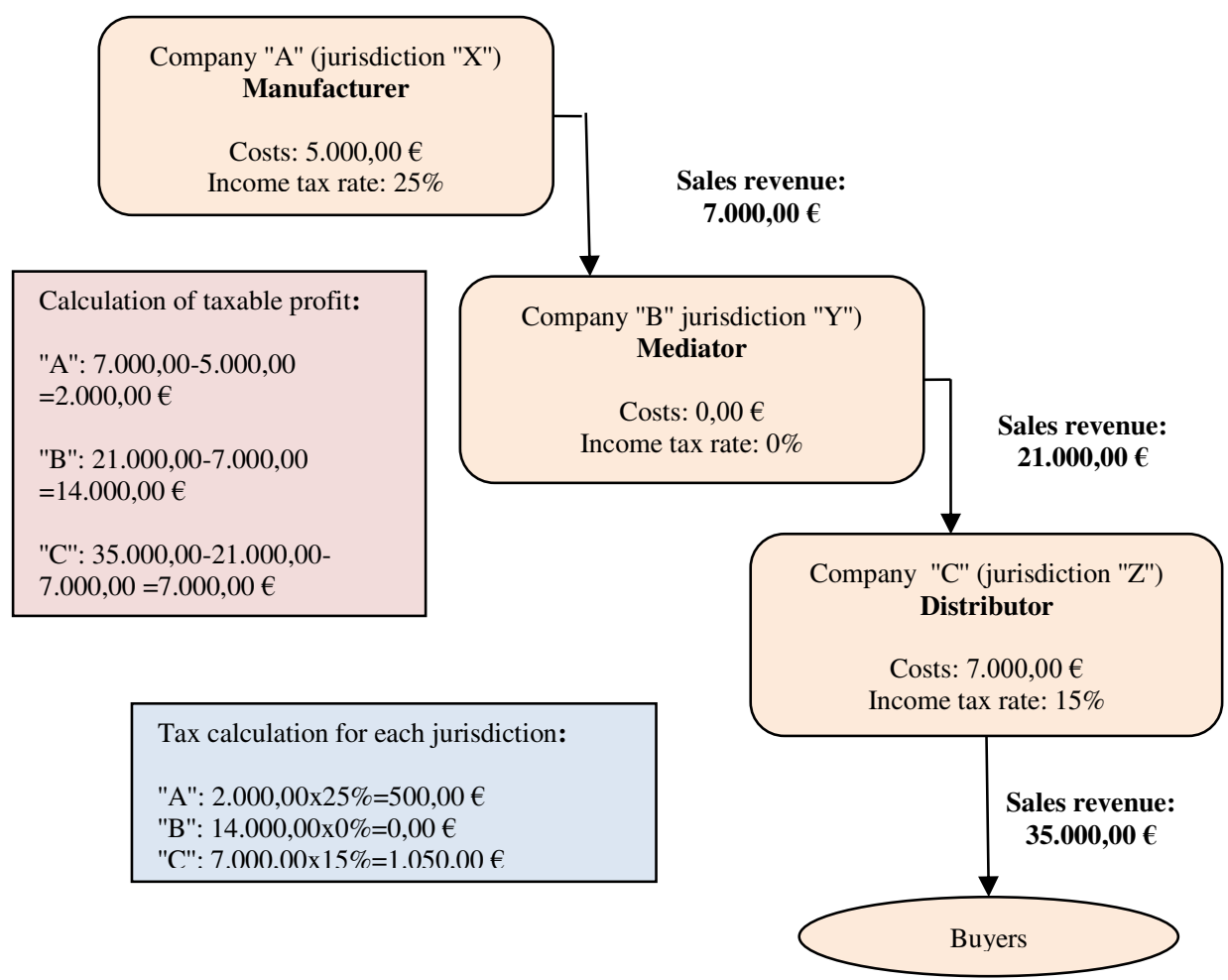

Figure 4. The application of transfer pricing between related legal entities

Note. Prepared by authors.

Considering all of the above, the key advantage of transfer pricing for the purpose of reducing tax liability is reflected in the high subjectivity of cost and revenue allocation mechanisms, which allows related entities a certain degree of discretion in their products/service allocation and certain location-allocation. On this basis, Sikka (2018, p. 13) emphasizes that tax avoidance strategies give large multinational businesses the opportunity to design complex corporate structures that use tax havens to divert profits, thus avoiding corporate taxes and securing additional cash flows. In other words, through transfer pricing, most of the profits are transferred to countries with more favorable tax competition instruments, thus minimizing the tax burden, with a parallel consequent increase in final profit.

Transfer pricing as part of aggressive tax planning has taken its full form with the development of the globalization process. Globalization has created the possibility for products, for example, to be designed in countries A and B, 
produced in countries $\mathrm{C}$ and $\mathrm{D}$, assembled in countries $\mathrm{E}$ and $\mathrm{F}$, while countries $\mathrm{G}$ and $\mathrm{H}$ have trademark and patent rights, and the rights to global marketing activities are granted to countries I and $\mathbf{J}$.

In this way, it is possible for national companies to become multinational, and for foreign companies to become part of the national business scene by establishing new companies, through joint ventures with local companies or through some other business combinations. In the 1970s, there were 7,000 multinational companies in the world, in 1998 there were just over 53,600, and in 2006 that number rose to 78,000 with at least 780,000 registered branches worldwide (Rixen, 2011, p. 207). With the increase in the number of multinational business entities, the volume of trade transactions within one business entity at the international level increases, and it is estimated that about $2 / 3$ of all business transactions in the world are performed within multinational companies or groups of related legal entities.

As early as the beginning of the 21st century, 51 out of the 100 largest economies in the world were multinational and transnational companies, not nation states. During that period, the 100 largest companies controlled $\$ 3.400$ billion in assets worldwide, $40 \%$ of which were located outside the home country (Sikka \& Willmott, 2010, p. 345). With the process of globalization, the dominance of multinational and transnational companies in the world economy has been achieved (Figure 5).

These data are not surprising considering the fact that it was already recorded in 2001 in the U.S.A. that trade between related legal entities accounts for $46 \%$ of total U.S. imports and 33\% of exports (Pak \& Zdanowicz, 2002). Zucman, in his 2015 paper, points out that 55\% of U.S. companies' foreign profits are reserved in tax havens. Cost-sharing arrangements (see more in: Barker, Asare \& Brickman, 2017), intragroup services, and transfer of intangible assets (see more in: Reineke \& Weiskirchner-Merten, 2018) have been identified as the main channels of transfer pricing abuse. 


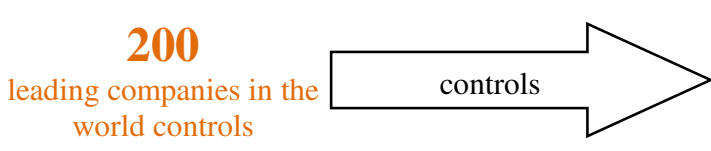

$\mathbf{2 8 \%}$ of world economic activity

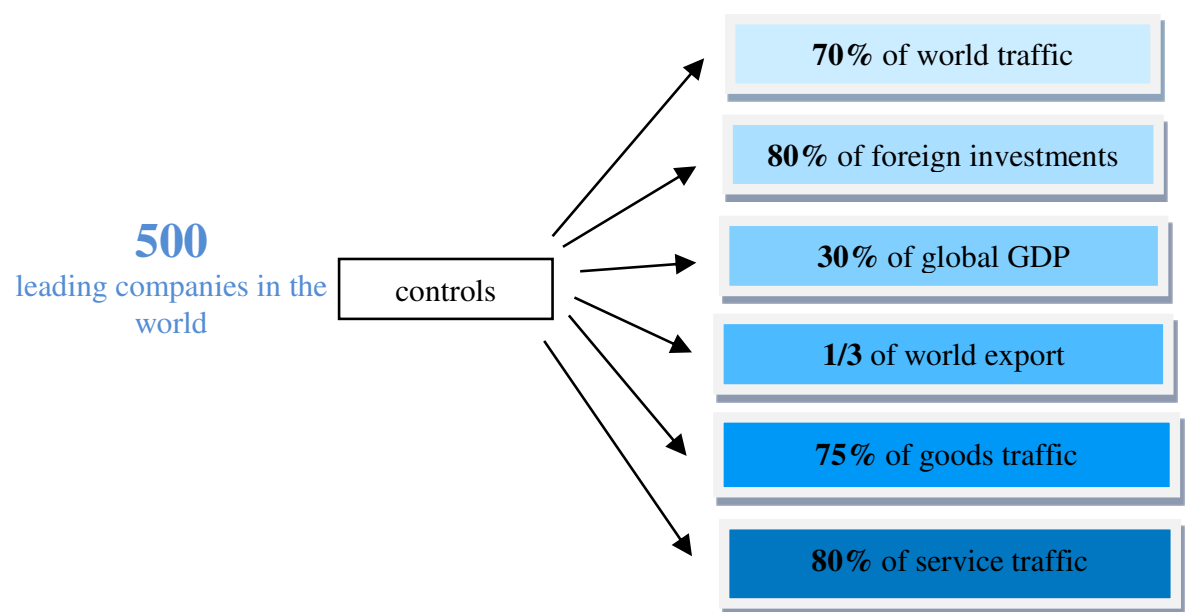

Figure 5. The dominance of multinational and transnational companies in world wealth

Note. Prepared by authors based on date retrieved from The dark side of transfer pricing: Its role in tax avoidance and wealth retentiveness, from Sikka, P. \& Willmott, H., (2010). Critical Perspectives on Accounting, 21(4), pp. 345-456.

Due to the lack of an adequate market for determining an impartial equivalent transaction (especially when companies use specific trademarks, patents, brands) or the monopolistic operations, it is very difficult to check whether there is a (mis)match of transfer pricing and the "out of reach" principle. For this reason, it is considered almost impossible, from the tax point of view, to accurately monitor all these transactions and provide a convincing quantification of the relative income through cross-border tax avoidance (Crivelli, De Mooij \& Keen, 2016, p. 20).

However, relying on data from the Bureau of Economic Analysis survey of U.S. multinational corporations from 1983 to 2012, Clausing points out in his 2016 paper that the U.S. lost between 77 and 111 billion dollars in income tax revenue by 2012 , which was more than $30 \%$ of U.S. income tax revenue, while for the entire world (including the U.S.) in 2012, the estimated loss on that basis was over $\$ 280$ billion. Cobham and Janský also estimated the annual global loss of about $\$ 500$ billion in 2019 , noting that the greatest intensity of losses occurs in low-income and lower middle income countries and across sub-Saharan Africa, Latin America and the Caribbean and South Asia. 


\section{THE OVERVIEW OF PROMINENT PRACTICAL EXAMPLES OF TRANSFER PRICING ABUSE}

Tax evasion due to inadequate application of transfer pricing is a serious global problem that threatens the stability of national tax systems in both developed and developing countries. In order to concretize and visualize the practical abuse of transfer pricing through the instruments of tax policy, below are various examples of the fraudulent application of controlled transfer pricing between related legal entities.

The data in Illustration 1 represent an extreme variant of transfer pricing abuse, but indicate that developed countries have also faced a widespread systematic approach to applying transfer pricing in any direction in order to avoid taxes and increase profits. Today, the oil industry, high-tech industry, chemical, and pharmaceutical industry represent the most expressive segment of the application of various arrangements around transfer prices around the world. This way of cheating the tax system enables "the protection of profits from taxation" in tax havens, while in the manufacturing countries the minimum amount of the tax base is recorded. The international non-governmental organization Oxfam found that US MNCs reported $\$ 80$ billion in profits in Bermuda in 2012 (a country identified by Oxfam as the largest corporate tax haven), more than their total reported profits in Japan, China, Germany, and France combined (Berkhout, 2016, p. 5). According to the results of the survey, which included more than 1,500 multinational businesses operating in India, it was found that multinational businesses that have related entities in tax havens reported $1.5 \%$ less profit and paid 30.3\% less tax per unit profit than multinational businesses that do not have related legal entities in tax havens (Jansky \& Prats, 2015, p. 280).

The frequency of the related practice is extremely difficult to estimate. Primarily because almost all of these types of aggressive tax planning (such as holding companies, capitalization, tax arbitration, and the application of transfer pricing) are more or less legal within certain tax systems and national tax authorities have no apparent basis to challenge the taxation procedure. Also, some countries (tax havens or jurisdictions with harmful tax practices) have no interest in cooperating with other countries in terms of exposing certain segments of aggressive tax planning, because it leads to an increase in national wealth. Based on this, the abuse of transfer pricing mainly becomes evident through sudden business collapses of companies, corruption investigations, investigative journalism, regulatory interventions, or court proceedings. 
In the USA, according to customs data, as well as data on exports and imports, in 2001 some products were imported at the following prices:

- \$972.98 / pc. plastic spoons (from the Czech Republic),

- $\$ 1,853.50 / \mathrm{pc}$. fences (from Canada),

- \$ 2,052.00 / 1 apple juice (from Israel),

- 4,121.81 / kg toilet paper (from China),

- \$4,896.00/ pc. tweezers (from Japan),

- \$8,500.00/ pc. ballpoint pens (from Trinidad).

While the export prices of certain American products were:

- \$1.20/ pc. prefabricated buildings (in Trinidad),

- \$1.75/ pc. portable toilet with tank (in Hong Kong),

- \$52.03 / pc. rocket and launcher (in Israel),

- \$387.83/ pc. bulldozer (in Venezuela).

Based on the above data, it is estimated that the U.S. government lost about $\$ 53.1$ billion in tax revenue in 2001 .

Illustration 1. Extreme transfer pricing abuse

Note. Retrieved from An estimate of 2001 lost US federal income tax revenues due to over-invoiced imports and under-invoiced exports from Pak, S.J., Zdanowicz, J.S., (2002), Working paper, Penn State University.

The two largest financial frauds, which were among the first to be detected in this way and which triggered a transfer pricing alarm as a means of abusing tax competition instruments, are shown in Table 2. 
Table 2

Accounting scandals based on the transfer pricing abuse

\begin{tabular}{|c|c|}
\hline \multicolumn{2}{|r|}{ „Enron“6 scandal (Houston, Texas) } \\
\hline Year/Activity & 2001, Electro distribution \\
\hline Scandal: & $\begin{array}{l}\text { Shareholders lost } \$ 74 \text { billion, thousands of employees and investors were left } \\
\text { without pension funds, and a large number of employees lost their jobs. }\end{array}$ \\
\hline $\begin{array}{l}\text { How was the } \\
\text { fraud } \\
\text { detected? }\end{array}$ & $\begin{array}{l}\text { High stock prices have fueled public suspicion, which was confirmed by the } \\
\text { internal auditor's report on accounting irregularities in the financial statements. }\end{array}$ \\
\hline $\begin{array}{l}\text { Results of } \\
\text { additional } \\
\text { investigation }\end{array}$ & $\begin{array}{l}\text { By creating 3,500 domestic and foreign branches (some of which were located } \\
\text { on the Turks and Caicos Islands, Bermuda and Mauritius), "Enron", in } \\
\text { accordance with the advice of the consulting companies "Arthur Andersen", } \\
\text { "Deloitte \& Touche" and cooperation with banks "Cash Manhattan", } \\
\text { "Deutsche Bank" and several leading law firms, developed a strategy of tax } \\
\text { avoidance through the income transfer to tax havens. Infrastructure } \\
\text { development projects in the countries where branches were established } \\
\text { brought Enron tax-free profits of } \$ 1.785 \text { billion in the period 1996-2000. The } \\
\text { essence of tax avoidance is reflected in the conception of an appropriate } \\
\text { transfer pricing policy. In the initial stages of project development, the project } \\
\text { was usually handed over to local companies, which were a joint venture of } \\
\text { "Enron" and at least two other companies registered in the Cayman Islands. } \\
\text { Such a business structure enabled, on one hand, the extraction of a large part } \\
\text { of taxable income to tax havens, and on the other hand, paid taxes and other } \\
\text { fees in tax havens were treated as a tax deduction in other jurisdictions. }\end{array}$ \\
\hline \multicolumn{2}{|r|}{ "WorldCom" scandal (Ashburn, Virginia) } \\
\hline Year/Activity & 2002, Electro distribution \\
\hline Scandal: & $\begin{array}{l}\text { In the financial reports, the number of funds was "inflated" by as much as } 11 \\
\text { billion dollars. } 30,000 \text { employees lost their jobs, and investors suffered a loss } \\
\text { of } 180 \text { billion dollars. }\end{array}$ \\
\hline $\begin{array}{l}\text { How was the } \\
\text { fraud } \\
\text { detected? }\end{array}$ & An internal audit revealed a fraud worth $\$ 3.8$ billion. \\
\hline $\begin{array}{l}\text { Results of } \\
\text { additional } \\
\text { investigatino }\end{array}$ & $\begin{array}{l}\text { For a fee of } \$ 9.2 \text { million, the consulting company "KPMG" advised a company } \\
\text { to increase its profit after tax by adopting a special transfer pricing program } \\
\text { for intangible assets. The company has created a product called "forecast } \\
\text { management" (a package of telecommunications services over a global } \\
\text { network that aims to create a horizontally and vertically integrated corporate } \\
\text { structure), as a hitherto unknown type of intangible asset. The parent company } \\
\text { registered this product in a low-tax jurisdiction and then licensed its } \\
\text { subsidiaries in high-tax jurisdictions for a certain amount of annual fee. In } \\
\text { this way, annual tax savings in the amount of } 25 \text { million dollars were ensured. } \\
\text { In the period } 1998-2001 \text {, the use of this license obtained over } \$ 20 \text { billion in } \\
\text { fees. Subsidiaries treated the license fee as an expense recognized for tax } \\
\text { purposes, while the revenue was transferred to a jurisdiction with a low tax } \\
\text { burden. This transfer pricing policy has enabled tax evasion in the amount of } \\
100 \text { to } 350 \text { million dollars. }\end{array}$ \\
\hline
\end{tabular}

Note. Prepared by authors based on several resources, retrieved from Healy \& Palepu (2003), Kaplan \& Kiron (2004), Kuhn \& Sutton (2006), Zekany, Braun \& Warder (2004). 
These accounting scandals were a "trigger" for more aggressive tax audits and legal actions of tax authorities in developed countries, in order to clarify and timely detect the use of transfer pricing as a means of abuse of tax competition instruments. By amending and completing the tax regulations, as well as by hiring an additional number of employees in the bodies for the implementation of tax control, a more detailed study of the corporate policy of the considered related legal entities was enabled. In this way, the tax authorities of developed countries have been able to, up to a point (in accordance with the data shown in Illustration 2), detect the inadequate application of transfer pricing and to make additional tax collections on that basis.

In the U.S., tax authorities are allowed to, in accordance with section 482 of the Internal Revenue Act, subsequently distribute revenues and expenses between related parties involved in controlled transactions, in order to prevent or reduce tax evasion. On that basis, in 2009, the US tax authorities hired 1,200 new workers for a detailed control of the application of transfer pricing, and in 2010 another 800.

In the United Kingdom, there were 1,724 corrections of tax calculation in 2005/2006 due to to subsequent corrections of transfer pricing by similar legal solutions with similar legal solutions. From 2005 to 2007, an additional $£ 1.1$ billion in taxes was levied on the basis of the respective corrections, while an additional $£ 2.1$ billion was levied in the following two-year period.

In Australia, in the period 2001-2005, a subsequent revision of transfer pricing collected an additional $\$ 2.5$ billion in income tax revenues.

Illustration 2. Additional tax collections based on subsequent adjustments to the application of transfer pricing

Note. Retrieved from The dark side of transfer pricing: Its role in tax avoidance and wealth retentiveness, od Sikka, P., Willmott, H., (2010). Critical Perspectives on Accounting, 21(4), p. 343.

Tax havens have a key role in the operations of multinational businesses when it comes to implementing a transfer pricing strategy. In practice, almost every day goods are physically moved from the sending country to the destination country, but from the aspect of financial records the transfer of goods is directed through tax havens with contracts (Illustration 3). 
A company located in the Caribbean deals with the delivery of bananas to a company located in the United Kingdom, with the contracted transactions being performed through related legal entities (Cayman Islands, Bermuda, Isle of Man, etc.). The selling price of 60 pence $/ \mathrm{kg}$ at which bananas are delivered to supermarkets in the UK consists of several elements:

- 13 pence / kg in the country of production (Caribbean), which includes 10.5 pence $/ \mathrm{kg}$ of production costs, 1.5 pence / $\mathrm{kg}$ of labor costs and 1.0 pence / $\mathrm{kg}$ of profit;

47 pence / $\mathrm{kg}$ of intragroup transactions, including 8 pence / $\mathrm{kg}$ for the use of the shopping channel network (Cayman Islands), 8 pence / $\mathrm{kg}$ for financial services (Luxembourg), 4 pence / $\mathrm{kg}$ based for the use of the trade name (Ireland), 4 pence / $\mathrm{kg}$ for insurance services (Isle of Man), 6 pence / $\mathrm{kg}$ for management services (Jersey) and 17 pence $/ \mathrm{kg}$ for the use of the distribution network (Bermuda).

Basically, a company pays itself for provided services and, since revenues are recorded in jurisdictions with low or zero tax burdens, 47 pence of revenue is virtually non-taxable.

Illustration 3. Banana trade through tax havens

Note. Retrieved from The dark side of transfer pricing: Its role in tax avoidance and wealth retentiveness, od Sikka, P., Willmott, H., (April 2010). Critical Perspectives on Accounting, 21(4), p. 351.

Large tax frauds, which accentuated the preferential tax treatment of MNCs in certain tax havens, also indicated the abuse of tax competition instruments by applying transfer pricing through advanced pricing agreements (APAs). The APA is a mechanism for ex ante dispute resolution between MNCs and the tax administration, where negotiations are not transparent (see more in: Markham, 2012; Byrnes \& Cole, 2018). As a rule, the APA is designed as a neutral tax procedure that improves the overall process of determining taxable income between MNCs and tax jurisdictions. However, given that these are individual agreements between MNCs and tax authorities, there is room for tax favoring of a particular MNC over other multinational as well as national businesses (Eden \& Byrnes, 2018, p. 11). At the end of 2013, the European Commission began a process of extensive investigations into the abuse of the APA arrangement in some member states by certain MNCs. Investigations showed that MNCs (in certain European tax havens), such as Apple - US (Ireland), Starbucks - US (Netherlands), Inter IKEA - Sweden (Netherlands), Fiat - Italy (Luxembourg), ENGIE - France (Luxembourg), Amazon - US (Luxembourg), McDonald's - US (Luxembourg), illegally reduced taxable profits and total tax payments (see more in: Lyal, 2015; Gormsen, 2016; Barrera \& Bustamante, 2017; Barker, 
Asare \& Brickman, 2017; Wang, 2018; Eden \& Byrnes, 2018). In order to indicate the impact of transfer pricing abuse on the economic, social, and tax stability of individual countries, it is important to point out that the estimated tax debt, based on the realized evasion, for e.g. Fiat and Starbucks, for 2012, amounted to between 20 and 30 million euros for each company (Europan Commission, 2015). Also, only for Apple, for the period 2003-2014, the estimated debt was approximately 13 billion euros (14.5 billion dollars), plus interest on unpaid taxes (Barrera \& Bustamante, 2017). This amount is equal to the annual cost of the Irish Health Service or a significant portion of the Irish national debt (Wang, 2018, p. 561).

Also, the International Consortium of Investigative Journalists, which has been working intensively in recent years to publish a number of discoveries, such as Luxembourg Leaks in 2014 (see more in: https://www.icij.org/investigations/luxembourg-leaks/), HSBC Leaks in 2015 (see more in: https://www.icij.org/investigations/swiss-leaks/), Offshore Leaks in 2015 (see more in: https://www.icij.org/investigations/offshore/ ), Panama Papers in 2016 (see more in: https://www.icij.org/investigations/panamapapers/), Paradise Papers in 2017 (see more in: https://www.icij.org/ investigations / paradise-papers /), Mauritius Leaks in 2019 (see more in: https://www.icij.org/investigations/mauritius-leaks/), showed that corporations are the main bearers of global tax avoidance. Disclosures have enabled the launch of major subsequent tax investigations and audits and income tax collections. Thus, e.g. in one of the largest and most comprehensive actions of investigative journalism "Panama Documents", an investigation was launched in 82 countries, and in the period 2016-2019, more than $\$ 1.2$ billion was reimbursed in only 22 countries. The investigations conducted have partially quantified the seriousness of transfer pricing abuse as a global issue that threatens the national budget revenues of a large number of countries.

These examples, as well as various studies, show that the misuse of tax competition instruments through transfer pricing is a serious global issue, on the basis of which some countries have lost astronomical amounts. For example, the United Kingdom lost $£ 12$ billion per year, while Germany lost $€ 90$ billion in tax revenue as a result of the transfer of profits, i.e. the base erosion (Fuest, Spengel, Finke, Heckemeyer \& Nusser, 2013, p. 9). Euronews data from 2013 indicated that EU member states together lost about one trillion euros each year. Also, there are estimates that between $\$ 7.6$ and $\$ 32$ billion, or about $8 \%$ of the world's wealth, is located in areas with low or zero tax burdens (Henry, 2012; Zucman, 2015). Various models estimate that global tax losses due to tax evasion by multinational businesses can amount to up to $\$ 600$ billion each year, 
approximately $\$ 400$ billion in developed countries and $\$ 200$ billion in developing countries (Crivelli et al. , 2016; Cobham and Janský, 2019). At the same time, developing countries are in a much more unfavorable position in terms of the abuse of transfer pricing for the purpose of reducing tax liability. Namely, their deficiency is reflected in the absence of adequate regulatory and control mechanisms, which is a consequence of the lack of financial resources, and thus the inability to hire experts to study in more detail the corporate policy of related legal entities regarding the application of transfer pricing. For this reason, transfer pricing is a challenge for developing countries, because their efforts to attract foreign investment through various instruments of tax competition may be responsible for the outflow of capital from these countries.

\section{CONCLUSION}

The data presented in the paper indicate that the creation of appropriate instruments of tax policy in terms of profit taxation affects the attraction of direct foreign investments. In addition, the noteceable application of various instruments of tax competition has conditioned a continuous trend of decreasing corporate tax rates at the global level, but the variability of these rates by continents and even within continents remains pronounced, taking into account the existence of tax havens.

The introduction of profit taxation in the source country sought to limit the abuse of tax competition instruments, but the process of globalization enabled the enormous growth of MNCs and, on that basis, a more intensive application of transfer pricing as a new source of their abuse. Transfer pricing, as the bearer of transactional relations between related legal entities, represent a means of exploiting the basic instruments of tax competition with the aim to increase the welfare of individual members within the group, as well as the group as a whole, leaving negative consequences on national tax systems and budgets.

Developed countries have introduced more aggressive tax audits and legal actions of tax authorities regarding the application of transfer pricing as a means of abusing tax competition instruments in order to protect the local tax base. However, in developing countries, due to the lack of financial and human resources to create an appropriate regulatory and control mechanism, the national tax base has remained a suitable area of tax evasion through the exploitation of tax competition instruments through the application of transfer pricing.

The main contribution of the paper is to quantify the magnitude of transfer pricing abuse and emphasize that it is still a growing tax problem of the $21^{\text {st }}$ century that requires more active global and national attention of developed countries, and especially of developing countries, by stating certain data and 
concrete examples of tax evasion. On this basis, it is necessary for the tax control authorities of developing countries to take the problem more seriously, and it would be desirable to consider the benefits of preferential tax competition instruments for national budgets, as well as and potential losses of their abuse through transfer pricing. It is very likely that the respective losses significantly outweigh the benefits. And as shown in the paper, in most situations, related abuse usually extends for a period of several years until the moment of its "accidental" disclosure, which means that the lack of data on the existence of transfer pricing abuse does not mean that it does not exist, but it may mean that the respective abuses and their impact on the national tax budget have not yet been publicly disclosed.

\section{REFERENCE}

Adams, L., \& Drtina, R. (2010). Multinational Transfer Pricing: Management Accounting Theory versus Practice. Management Accounting, 11(3), 22-29.

Barker, J., Asare, K., \& Brickman, S. (2017). Transfer Pricing as a Vehicle in Corporate Tax Avoidance. The Journal of Applied Business Research, 33(1), 9-16.

Barrera, R., \& Bustamante, J. (2017). The Rotten Apple: Tax Avoidance in Ireland. The International Trade Journal, 32(1), 150-161.

Berkhout, E. (2016). Tax Battles: The dangerous global race to the bottom on corporate tax. Oxford: Oxfam International

Buettner, T., Overesch, M., \& Wamser, G. (2018). Anti profit-shifting rules and foreign direct investment. International Tax and Public Finance, 25(3), 553-580.

Byrnes, W., \& Cole, R. (2018). Practical Guide to U.S. Transfer Pricing. New York: Lexis Nexis.

Cazacu (Neamtu), A. L. (2017). Transfer prices - an international problem. Junior Scientific Researcher, 3(2), 19-25.

Chirculescu, M. F. (2018). Advantages and disadvantages of tax competition in the European Union. Annals of the "Constantin Brâncuşi”" University of Târgu Jiu, Economy Series, 186-192. 
Cobham A., \& Janský P. (2019). Measuring misalignment: the location of US multinationals' economic activity versus the location of their profits. Development Policy Review, 37(1), 91-110.

Cottani G. (2018). Transfer pricing. IBFD.

Clausing, K. A. (2016), The Effect of Profit Shifting on the Corporate Tax Base in the United States and Beyond. National Tax Journal, 69(4), 905934.

Crivelli, E., De Mooij, R., \& Keen, M. (2016). Base erosion, profit shifting and developing countries. Public Finance Analysis, 72(3), 268-301.

Davies, R. B., Martin, J., Parenti, M., \& Toubal, F. (2018). Knocking on Tax Haven's Door: Multinational Firms and Transfer Pricing. Review of economics and Statistics, 100(1), 120-134.

Deloitte. Deloitte International Tax Guide. Retrieved from https://dits.deloitte.com/\#TaxGuides

Eden, L., \& Byrnes, W. (2018). Transfer pricing and state aid: the unintended consequences of advance pricing agreements. Transnational Corporations, 25(2), 9-36.

Elkins, D. (2016). The Merits of Tax Competition in a Globalized Economy. Indiana Law Journal, 91(3), 905-954.

Euronews. (2013). Europe's battle against 1 trillion tax evasion. Retrieved from: https://www.euronews.com/2013/05/21/web-as-europe-facestax-evasion-worth-1-trillion-euro-meps-debate-solutions-ahe.

European Commission. (2015). Commission decides selective tax advantages for Fiat in Luxembourg and Starbucks in the Netherlands are illegal under $E U$ state aid rules. Retrieved from https://ec.europa.eu/commission/presscorner/detail/en/IP_15_5880

Fuest, C., Spengel, C., Finke, K., Heckemeyer, J., \& Nusser, H. (2013). Profit Shifting and "Aggressive" Tax Planning by Multinational Firms: Issues and Options for Reform. ZEW Discussion Papers, 13-044.

Gormsen, L. L. (2016). EU State Aid Law and Transfer Pricing: A Critical Introduction to a New Saga. Journal of European Competition Law \& Practice, 7(6), 369-381.

Healy, P. M., \& Palepu, K. G. (2003). The Fall of Enron. Journal of Economic Perspectives, 17(2), 3-26. 
Henry, J. S. (2012). The price of offshore revisited: new estimates for missing global private wealth income inequality and lost taxes. Tax Justice Network, 22, 57-168.

Jakšić, D., Andrić, M., \& Mijić, K. (2014). Uticaj globalnih promena na oporezivanje dobiti - obračun transfernih cena. U: Uticaj globalnih promjena na ekonomiju zemalja u tranziciji. Bijeljina: Fakultet poslovne ekonomije.

Jansky, P., \& Prats, A. (2015). International Profit-Shifting out of Developing Countries and the Role of Tax Havens. Development Policy Review, 33(3), 271-292.

Jost, S. P., Pfaffermayr, M., \& Winner, H. (2014). Transfer pricing as a tax compliance risk. Accounting and Business Research, 44(3), 260-279.

Kaplan, R. S., \& Kiron, D. (2004). Accounting Fraud at WorldCom. In Cummings, L \& Millanta, B. (Eds), Financial Accounting Theory and Practice (2nd ed.). Sydney: McGraw Hill Australia Pty Ltd.

KPMG. Corporate tax rates table. Retrieved from https://home.kpmg.com/xx/en/home/services/tax/tax-tools-and-resources/taxrates-online/corporate-tax-rates-table.html

Kuhn, J. R., \& Sutton, S. G. (2006). Learning from WorldCom: Implications for Fraud Detection through Continuous Assurance. Journal of Emerging Technologies in Accounting, 3(1), 61-80.

Lyal, R. (2015). Transfer Pricing Rules and State Aid. Fordham International Law Journal, 38(4), 1017-1043.

Lohse, T., Riedel, N., \& Spengel, C. (2014). The Increasing Importance of Transfer Pricing Regulations: A Worldwide Overview. Inertax, 42(6/7), 352404.

Markham, M. (2012). Advance Pricing Agreements: Past, Present and Future. Amsterdam, Netherlands: Kluwer Law International.

Mikerević, D. (2011). Poresko okruženje kao faktor opstanka, rasta i razvoja preduzeća. Naučni časopis za ekonomiju Financing, II(2), 5-19. 20-27.

Paić, P. (2012). Uticaj poreza na međunarodnu razmjenu. Finrar, 10/12,

Pak, S. J. (2012). Lost billions: Transfer Pricing in the Extractive Industries. Norway: Publish What You Pay. 
Pak, S. J., \& Zdanowicz, I. S. (2002). An estimate of 2001 lost US federal income tax revenues due to over-invoiced imports and under-invoiced exports. Working paper. Penn State University.

Pezerović, A. (2012). Osnovne tendencije razvoja sistema oporezivanja dobiti. Naučni časopis za ekonomiju Financing, III(1), 26-34.

Pezerović, A. (2013). Upotreba transfernih cijena sa stanovišta poreza na dobit. Naučni časopis za ekonomiju Financing, IV(2), 12-21.

Rectenwald, G. (2012), A Proposed Framework for Resolving the Transfer Pricing Problem: Allocating the Tax Base of Multinational Entities Based on Real Economic Indicators of Benefit and Burden. Duke Journal of Comparative \& International Law, 22(3), 425-449.

Reineke, R., \& Weiskirchner-Merten, K. (2018). Transfer Pricing and Location Choice of Intangibles Spillover and Tax Avoidance through Profit Shifting. WU International Taxation Research Paper Series, (2019-01).

Shin. M. J. (2017). Partisanship, Tax Policy and Corporate Profit-Shifting in a Globalized World Economy. Comparative Political Studies, 50(14), 19982026.

Sikka, P., \& Willmott, H., (2010). The dark side of transfer pricing: Its role in tax avoidance and wealth retentiveness. Critical Perspectives on Accounting, 21(4), 342-356.

Sikka, P. (2018). Combating corporate tax avoidance by requiring large companies to file their tax returns. Journal of Capital Markets Studies, 2(1), 920.

Tax Foundation. Corporate Income Tax Rate around the World. (2018). Retrieved from https://taxfoundation.org/publications/corporate-tax-ratesaround-the-world/

The International Consortium of Investigative Journalists. (2014). Luxembourg Leaks. Retrived from ttps://www.icij.org/investigations/luxembourg-leaks/

The International Consortium of Investigative Journalists. (2015). HSBC Leaks. Retrived from https://www.icij.org/investigations/swiss-leaks/

The International Consortium of Investigative Journalists. (2015). Offshore Leaks. Retrived from https://www.icij.org/investigations/offshore/ 
The International Consortium of Investigative Journalists. (2016). Panama Papers. Retrived from https://www.icij.org/investigations/panamapapers/

The International Consortium of Investigative Journalists. (2017). Paradise Papers. Retrived from https://www.icij.org/investigations/paradisepapers/

The International Consortium of Investigative Journalists. (2019). Mauritius Leaks. Retrived from https://www.icij.org/investigations/mauritiusleaks/

Zekany, K. E., Braun, L.W., \& Warder, Z. T. (2004). Behind Closed Doors at WorldCom: 2001. Accounting Education, 19(1), 101-117.

Zucman, G. (2015). The Hidden Wealth of Nations: The Scourge of Tax Havens. Chicago: University of Chicago Press.

Wang, B. (2018). After the European Commission Ordered Apple to Pay Back Taxes to Ireland: Ireland's Future in the New Global Tax Environment. Indiana Journal of Global Legal Studies, 25(1), 539-564.

Delivered: 17.06.2019. Accepted: 21.10.2020. 